\title{
Comparative Analysis of the Fruit Pericarp Structure of the Desert and Mountain Species of Ferula L. (Apiaceae Lindl.)
}

\author{
Vasila K. Sharipova \\ Institute of Botany and zoology Academy of Sciences of Uzbekistan, Tashkent, Uzbekistan \\ Email: vasila_82@mail.ru
}

How to cite this paper: Sharipova, V.K. (2017) Comparative Analysis of the Fruit Pericarp Structure of the Desert and Mountain Species of Ferula L. (Apiaceae Lindl.). American Journal of Plant Sciences, 8, 2013-2020.

https://doi.org/10.4236/ajps.2017.89134

Received: June 9, 2017

Accepted: July 30, 2017

Published: August 2, 2017

Copyright $\odot 2017$ by author and Scientific Research Publishing Inc. This work is licensed under the Creative Commons Attribution International License (CC BY 4.0).

http://creativecommons.org/licenses/by/4.0/

\begin{abstract}
It has described structure of the pericarp of 6 Ferula species fruits in natural habitat conditions: Nuratau range and Kyzylkum Desert. Differences in the location and structure of the secretory conceptacles have been discovered due to their biomes and habitat conditions. Secretory tubules of mature fruit pericarp (Scorodosma subgenus) F. foetida obliterated. In the pericarp (Macrorrhiza section) of $F$. varia fruit, there are two types of secretory structures: dorsal and commissural. In the fruit pericarp of (Xeronarthex section) F. kyzylkumica, $F$. helenae, $F$. dshizakensis and $F$. angreni species, there are three types: dorsal, commissural and costal, which increase their drought resistance and reflect a higher evolutionary level of taxa [1].
\end{abstract}

\section{Keywords}

Ferula, Fruit, Anatomy, Secretory Structure, Adaptation

\section{Introduction}

Apiaceae Lindley family spreads across the globe. A center of diversity of the family is considered Middle Asia. Many types of umbellate are of great importance in the composition of vegetation cover, as dominants of mountainous and arid regions [2]. Ferula species figure prominently in today's complex investigation of umbellate. The study of the secretory system of different organs and characteristics of terpene-containing conceptacles are important to determine the localization of some biologically active compounds [3].

Features of the pericarp histological organization of fruit species of Umbelliferae family are used on solution of taxonomical and phylogenic problems. Among the carpological features, secretory system type endosperm is taxonomically 
most valuable conductive. Systematics of Ferula genus is based on carpologicalanatomical signs [2] [3] [4] [5]. In Kazakhstan conditions, 48 species of the genus Ferula L. including F. foetida (Bunge) Regel, F. varia (Schrenk) Trautv. F. $d$ shizakensis Korovin and $F$. angreni Korovin were studied in synonymy, carpology, ecology, distribution, chemical composition, and economic value [3]. In the description of the pericarp, we took into account the quantitative indicators of secretory structures, life form and habitat. For the first time it has been studied in detail anatomical structure of endem species F. kyzylkumica and F. helenae pericarp.

\section{Materials and Methods}

Material has been collected in Nuratau Mountains and Southwestern Kyzylkum deserts (Figure 1). Pericarps of 6 species of genus Ferula out of 2 subgenera have been studied: 1. Scorodosma subgenus (Bunge) Drude-F. foetida (Bunge) Regelmonocarpic and grows on the southern piedmont plain of Kuldzhuktau on sandy, saline soils with shallow gypsum. 2. Peucedanoides subgenus (Boiss.)- $F$. varia (Schrenk) Trautv.-monocarpic, grows on rocky slopes of Kuldzhuktau; $F$. kyzylkumica Korovin-polycarpic, endemic, grows on speckled remnant mountains; F. helenae Rakhmankulov et Melibaev-monocarpic, endemic, grows on stony slopes in the middle belt of Nuratau, Pistalitau mountain; F. dshizakensis Korovin-polycarpic on small-crushed stone slopes around the rocky outcrops, stony ridges of Nuratau; $F$. angreni Korovin-polycarpic, on soft steppe slopes, gravelly scree, Nuratau and Malguzar.

Fruits were fixed in $70^{\circ}$ of ethanol. Cross sections of fruit are made by hand. Preparations were stained with safranin, methylene blue, sealed with glycerol-

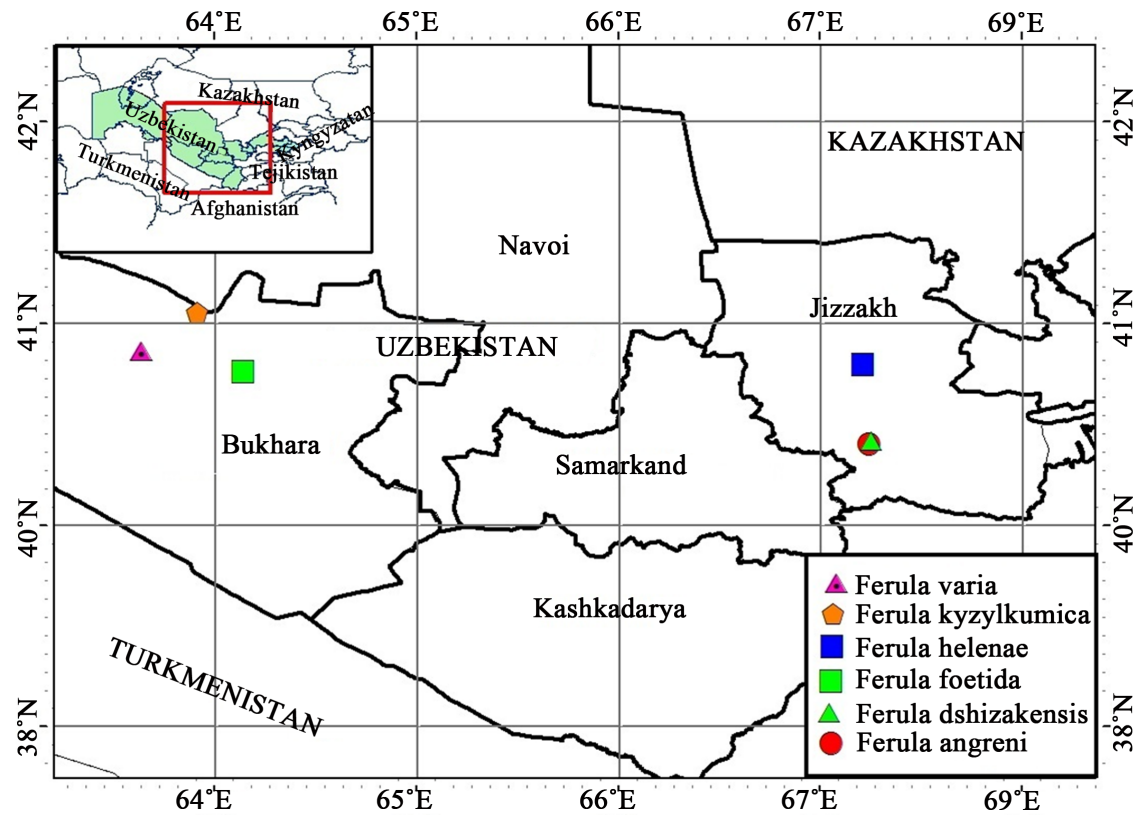

Figure 1. Distribution map of species of the genus Ferula on Nuratau and Southwestern Kyzylkum. 
gelatin. Size of secretory conceptacles, the length and width of the epithelial cells were measured by ocular micrometer-MOU-1.5 in the standard technique [6]. Mathematical processing carried out by the method of G.N. Zaitsev [7] using a personal computer (MS Excel). Preparations were sketched using a drawing apparatus RA-6. The micrographs were taken by a computer with photo micro nozzle digital Samsung camera.

\section{Results and Discussion}

The fruit of Ferula species-cremocarp, at ripening disintegrates into two mericarp hanging on dicranotrichous-branched column (carpophorus). Mericarp with filamentary or almost imperceptible wing-shaped ribs. Fruits are aerochorous. Mericarp differ in shape: round-oval or elliptical, flat-compressed $(F$. foetida, F. varia), oblong-oval ( F. kyzylkumica, F. helenae, $F$. angreni), obovate (F. dshizakensis).

The largest mericarp $12-16 \mathrm{~mm}$ long, $8-11 \mathrm{~mm}$ in width of $F$. foetida, $F$. angreni and $F$. varia, small-7.5 mm long and-4.5 in width of $F$. kyzylkumica (Table 1). Hallmarks of the fruit are the wing edge pubescent ribs (F. foetida),

Table 1. The morphological and structural features of the fruit species Ferula.

\begin{tabular}{|c|c|c|c|c|c|c|c|}
\hline \multicolumn{3}{|c|}{ Indicators } & F. helenae & F. dshizakensis & F. angreni & F. varia & F. kyzylkumica \\
\hline \multicolumn{3}{|c|}{ fruit length, mm } & $9.1 \pm 0.01$ & $9.5 \pm 0.01$ & $13.2 \pm 0.01$ & $12.9 \pm 0.01$ & $7.5 \pm 0.01$ \\
\hline \multicolumn{3}{|c|}{ Width. mm } & $4.2 \pm 0.009$ & $6 \pm 0.01$ & $7.8 \pm 0.01$ & $9.1 \pm 0.01$ & $4.5 \pm 0.009$ \\
\hline \multicolumn{3}{|c|}{ The weight of 1000 pcs. of fruits, g. } & 21.61 & 38.95 & 45.66 & 36.65 & 19.20 \\
\hline \multirow{4}{*}{\multicolumn{2}{|c|}{ The number of secretory tubules }} & \multirow{2}{*}{$\begin{array}{c}\text { dorsal } \\
\text { comissural }\end{array}$} & 4 & 4 & $4.86 \pm 0.18$ & 4 & 4 \\
\hline & & & $3.13 \pm 0.06$ & $8.03 \pm 0.14$ & $6.5 \pm 0.19$ & $2.43 \pm 0.09$ & $7.56 \pm 0.12$ \\
\hline & & dorsal & 3 & 3 & 3 & absent & 3 \\
\hline & & boundary & absent & $2.33 \pm 0.08$ & $3.3 \pm 0.08$ & absent & $2.96 \pm 0.05$ \\
\hline \multirow{6}{*}{\multicolumn{2}{|c|}{$\begin{array}{l}\text { Size secretory } \\
\text { tubules, } \mu \mathrm{m}\end{array}$}} & dorsal: major axis & $598.5 \pm 2.72$ & $1039.65 \pm 4.75$ & $604.75 \pm 3.01$ & $453.65 \pm 2.66$ & $583.3 \pm 2.34$ \\
\hline & & minor axis & $95.9 \pm 1.23$ & $278.65 \pm 2.45$ & $75.75 \pm 1.32$ & $72.55 \pm 0.71$ & $138.95 \pm 1.69$ \\
\hline & & comiss.: major axis & $663.05 \pm 2.52$ & $738.05 \pm 2.86$ & $425.95 \pm 1.59$ & $212.09 \pm 1.03$ & $263.6 \pm 1.73$ \\
\hline & & minor axis & $107.3 \pm 1.05$ & $199.75 \pm 1.28$ & $57.25 \pm 0.67$ & $54.75 \pm 0.56$ & $58.8 \pm 0.58$ \\
\hline & & dorsal edge & $32.47 \pm 0.29$ & $50.24 \pm 0.51$ & $31.73 \pm 0.29$ & absent & $28.45 \pm 0.42$ \\
\hline & & boundary edge & absent & $58.59 \pm 0.51$ & $49.64 \pm 0.44$ & absent & $51.57 \pm 0.50$ \\
\hline \multirow{8}{*}{$\begin{array}{l}\text { The size of the } \\
\text { epithelial cells } \\
\text { of the secretory } \\
\text { tubules, } \mu \mathrm{m}\end{array}$} & \multirow{2}{*}{ dorsal } & height & $15.16 \pm 0.15$ & $23.96 \pm 0.29$ & $13.78 \pm 0.21$ & $11.85 \pm 0.15$ & $14.13 \pm 0.23$ \\
\hline & & width & $36.94 \pm 0.32$ & $49.28 \pm 0.55$ & $33.46 \pm 0.40$ & $20.4 \pm 0.41$ & $39.08 \pm 0.32$ \\
\hline & \multirow{2}{*}{ comissural } & height & $13.14 \pm 0.15$ & $15.86 \pm 0.19$ & $13.62 \pm 0.19$ & $7.96 \pm 0.18$ & $16.46 \pm 0.24$ \\
\hline & & width & $31.74 \pm 0.22$ & $43.9 \pm 0.64$ & $32.14 \pm 0.23$ & $14.33 \pm 0.36$ & $31.56 \pm 0.39$ \\
\hline & \multirow{2}{*}{ dorsal edge } & height & absent & $16.13 \pm 0.24$ & $7.24 \pm 0.19$ & absent & $7.73 \pm 0.15$ \\
\hline & & width & absent & $9.68 \pm 0.14$ & $13.94 \pm 0.21$ & absent & $11.61 \pm 0.13$ \\
\hline & \multirow{2}{*}{ boundary edge } & height & absent & $7.38 \pm 0.19$ & $10.72 \pm 0.16$ & absent & $10.78 \pm 0.13$ \\
\hline & & width & absent & $19.06 \pm 0.29$ & $23.16 \pm 0.28$ & absent & $17 \pm 0.15$ \\
\hline \multirow{4}{*}{\multicolumn{2}{|c|}{$\begin{array}{l}\text { The number of epithelial } \\
\text { cells secretory tubules }\end{array}$}} & dorsal & $42.39 \pm 0.66$ & $52.73 \pm 0.57$ & $45.83 \pm 0.66$ & $44.5 \pm 0.41$ & $41.4 \pm 0.36$ \\
\hline & & comissural & $30.46 \pm 0.38$ & $41.53 \pm 0.56$ & $32.9 \pm 0.47$ & $37.62 \pm 0.38$ & $19.47 \pm 0.15$ \\
\hline & & dorsal edge & absent & $11.66 \pm 0.19$ & $7.76 \pm 0.13$ & absent & $9.73 \pm 0.11$ \\
\hline & & boundary edge & absent & $11.53 \pm 0.20$ & $9.6 \pm 0.19$ & absent & $11.38 \pm 0.15$ \\
\hline
\end{tabular}

Note: Indicators of secretory structures $F$. foetida in the table are not shown, due to their lack of mature fruit. 
flat-compressed form (F. varia), the convex surface of the dorsal and ventral concave in other species (Figure 2). Pericarp is composed of 3 layers: exocarp, mesocarp and endocarp. Exocarp is single-row, with thickened outer walls, cells of the small dorsal ribs.

Exocarp of $F$. foetida, $F$. varia and $F$. dshizakensis is large, F. kyzylkumica, $F$. helenae and $F$. angreni-parvicellular. Under exocarp it is placed one or two-row sub epidermis. Mesocarp consists of 2 layers: the outer parenchyma, including the secretory tubules, and internal-hypoendocarp composed of sclerenchyma fibers and hydrocyte fibers. Mesocarp parenchyma is thin-walled, composed of several layers of cells.

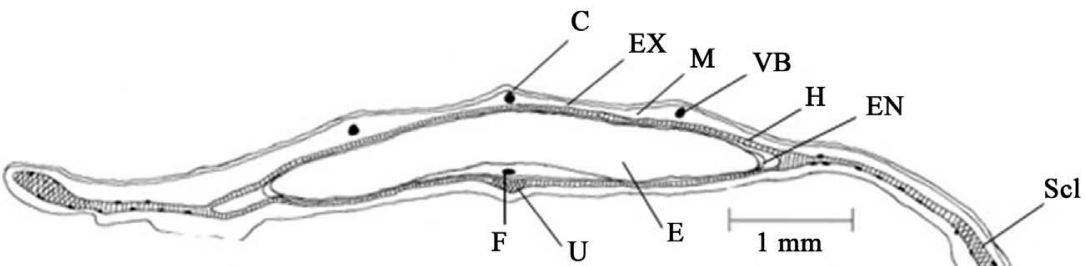

(a)

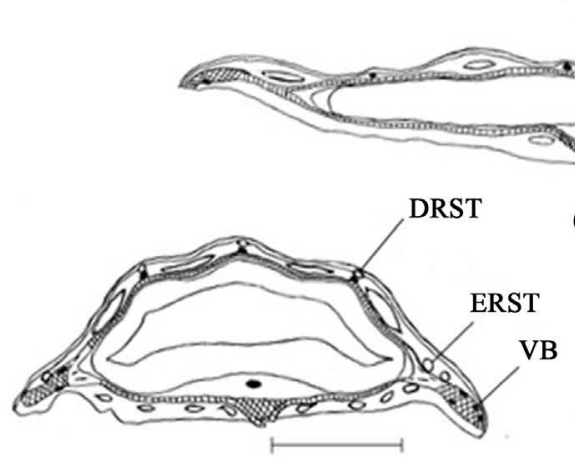

(c)

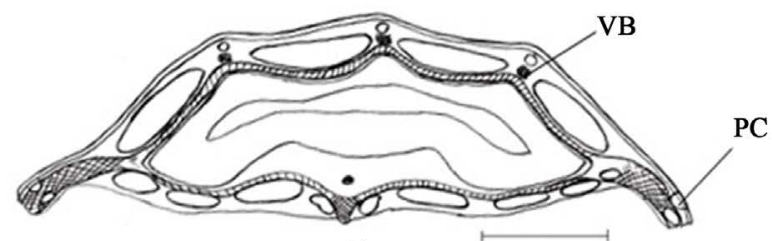

(e)

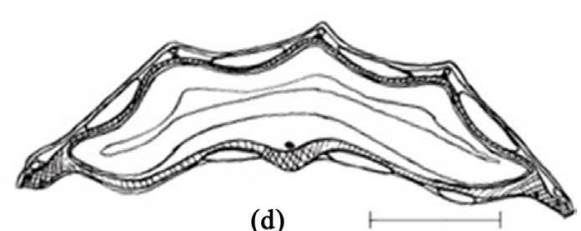

(d)

S

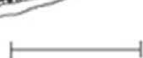

(b) CST

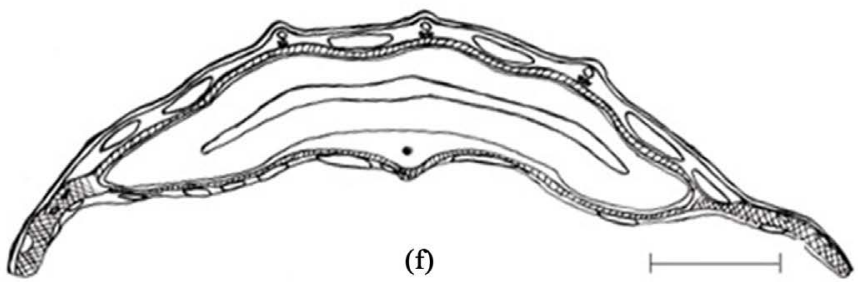

Figure 2. The structure of the fruit species Ferula: (a) cross section mericarp F. foetida; (b) F. varia; (c) F. kyzylkumica; (d) F. helenae; (e) F. dshizakensis; (f) F. angreni. Symbols: C-The Cuticle, CST-Commissural Secretory Tubules, DRST—Dorsal Rib Secretory Tubules, DST-Dorsal Secretory Tubules, E-Endosperm, EN-Endocarp, ERST-Edge Rib Secretory Tubules, EX-Exocarp, F-Funikulus, H-Hypoendocarp, M-Mesocarp, PC-Pneumatic Cavities, S-Spermoderm, Scl-Sclerenchyma, VB-Vascular Bundle, U-Umbilicus. Drawing scale: (a)-(f) $-1 \mathrm{~mm}$. 
The dorsal ribs are vascular bundles which are adjacent portions of sclerenchyma, followed by 2 - 3 tubular rib. Hypoendocarp consists of cells with slit pore.

Sclerefication of hypoendocarp is different. Endocarp is represented by one row of cells, sometimes fused with a single-layer spermoderm. In the boundary edge the bulk constitutes sclerenchyma cells with thickened walls. Vascular bundles and edge rib secretory tubules are located on both sides of the boundary edge. Funiculus with large vascular bundles. Adhesion of a column is roundedtriangular includes vascular bundle with spiral thickening of vessel walls, surrounded by hydrocyte cells.

The endosperm is well developed. The secretory system consists of dorsal, commissural, rib tubules. 4 secretory tubules are located in the hollows. They are extended in tangential direction in cross-section. On the dorsal (abdominal) side are commissural tubules. Secretory tubules are lined with epithelial cells.

The numbers of outer rows of parenchyma in different species are different2 - 3 in F. helenae, 3 - 4 in F. foetida, F. varia, F. kyzylkumica, F. dshizakensis and $F$. angreni. Conductive bundles are more developed in F. foetida, F. kyzylkumica, F. helenae, F. dshizakensis, less in F. varia and F. angreni. Fruits of $F$. foetida differ from other species in the presence of external parenchymal cells on both sides of mericarp tarry substances.

This gives to fruit a specific smell and a yellowish-brown color. Perhaps this is due to obliteration of the secretory tubules of immature and mature fruit. However, the secretory tubules are in the walls of the ovary. Sclerefication of hypoendocarp is different: hypoendocarp of $F$. foetida is made up of fibrous cells with thickened walls and a well-defined pore, in $F$. varia-consists of a thickwalled fiber cells with slit pore and connects with main array sclerenchymatous edge ribs with narrow isthmus. In F. kyzylkumica, $F$. helenae, $F$. dshizakensis and $F$. angreni hypoendocarp consists of weakly lignificated prosenchyma cells with large and small slit pore (Figure 3).

In all species endocarp is single-row and consists of rectangular cells. Spermoderm is dark brown, single-rowed. Boundary edges form in all species is different. Wide rib in $F$. foetida, elongated and thin in $F$. varia, wing-shaped in $F$. kyzylkumica, short wing-shaped in $F$. helenae, elongated wing-shaped in $F$. dshizakensis, elongated in $F$. angreni. In all species in the apical part of the boundary edges under the exocarp sclerenchyma cells are arranged subepidermal and thick-walled sclerenchyma. The main part of the boundary edges-the jumper from the elongated strand of large cells with fine pore (Figure 4).

In the distal part there is a of sclereid in F. varia, F. dshizakensis and F. angreni. On both sides of the boundary edges are $4-6$ vascular bundles in the dorsal ribs-3 sclereficated vascular bundles in $F$. varia, F. kyzylkumica, $F$. helenae, $F$. $d$ shizakensis and $F$. angreni. The boundary edge of $F$. foetida has 8 - 11 vascular bundles, and from the dorsal ribs-3 - 5 vascular bundles. On both sides of the boundary edges $F$. helenae, $F$. dshizakensis and $F$. angreni there are pneumatic 


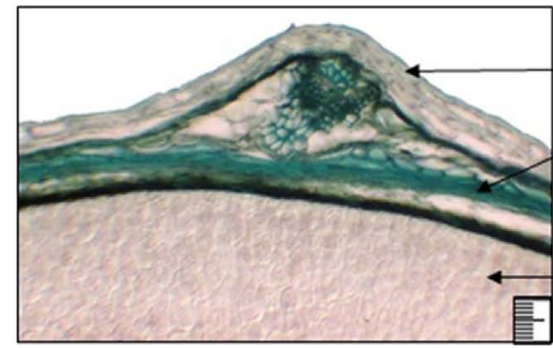

(a)

$100 \mu \mathrm{m}$

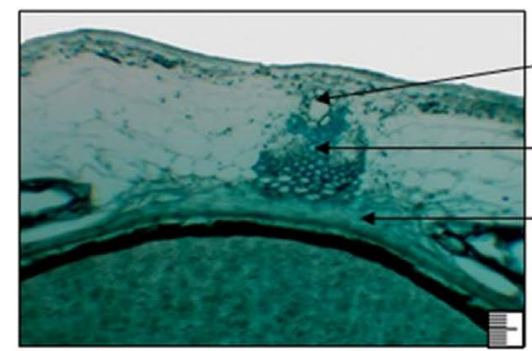

(c)

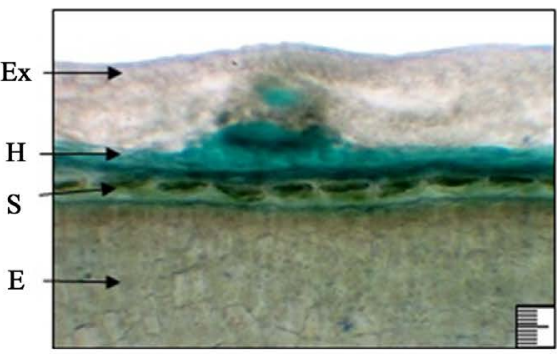

(b)

$100 \mu \mathrm{m}$

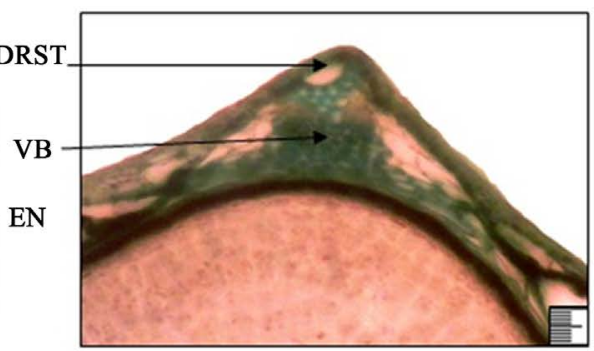

(d)

$100 \mu \mathrm{m}$
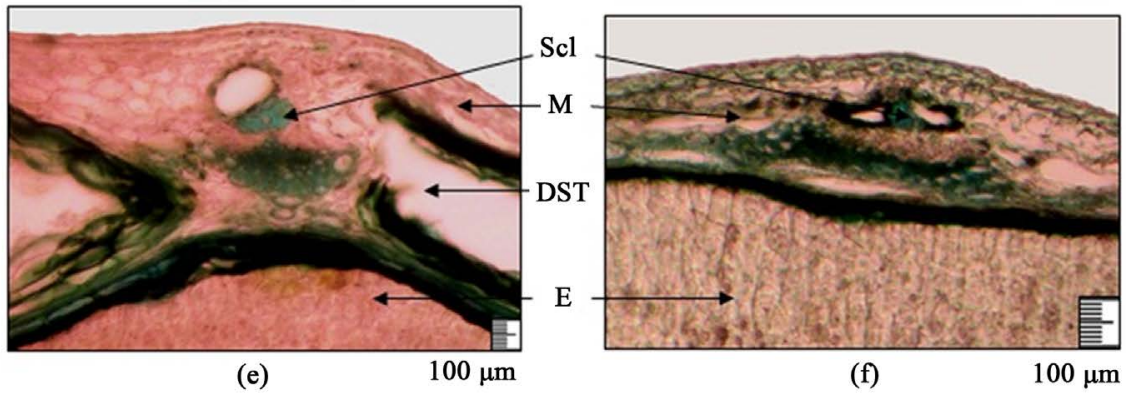

(f)

Figure 3. Cross section mericarp dorsal side of species Ferula: (a) F. foetida; (b) F. varia; (c) F. kyzylkumica; (d) F. helenae; (e) F. dshizakensis, (f) F. angreni. Symbols: DRSTDorsal Rib Secretory Tubules, DST-Dorsal Secretory Tubules, E-Endosperm, EN-Endocarp, EX-Exocarp, H-Hypoendocarp, M-Mesocarp, S-Spermoderm, Scl-Sclerenchyma, VB-Vascular Bundle. Drawing scale: (a)-(f) - $100 \mu \mathrm{m}$.

cavities. The bundle of funiculus (raphe) of $F$. foetida with numerous vascular elements, large-formed thick-walled sclerenchyma. Umbilicus of a column is sclerenchymatous, surrounded by hydrocyte cells. In $F$. varia and $F$. angreni funiculus with a large vascular bundles. Umbilicus form is triangular, composed of sclerenchyma surrounded by hydrocyte cells. In F. kyzylkumica, F. helenae and F. dshizakensis funiculus is small, with a few thick-walled vessels. Umbilicus of a column is triangular shaped, consists of thick-walled cells surrounded by hydrocyte cells.

A number of dorsal tubules in all species almost the same (4), in F. angreni to 6. Commissural tubules more in $F$. dshizakensis (8), less in $F$. helenae (3). Rib tubules of 2 types: dorsal and edge (not having any in $F$. varia). A number of dorsal rib tubules of all studied species stably (3). The edge rib tubules absent in the fruit of F. helenae, in F. kyzylkumica, F. dshizakensis and F. angreni closed (2 - 3). Dorsal, commissural and edge tubules on the major and minor axes 


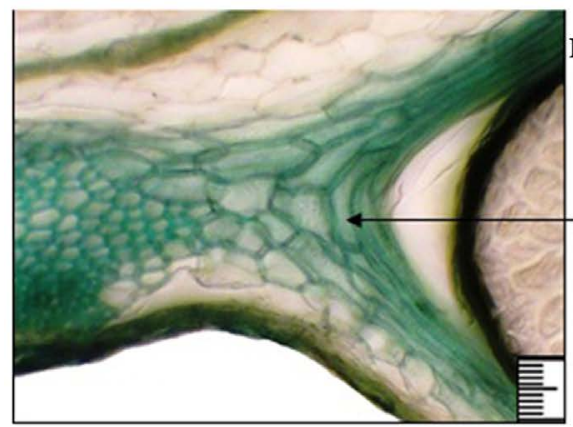

(a)

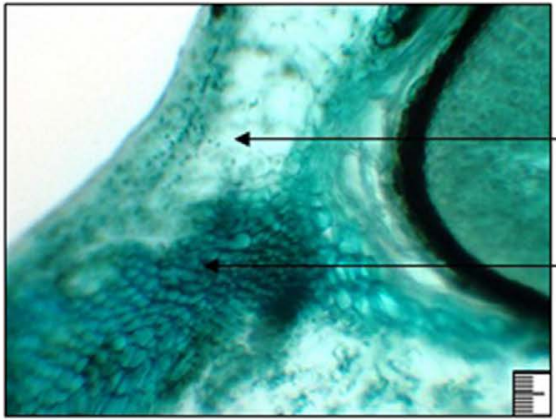

(c)

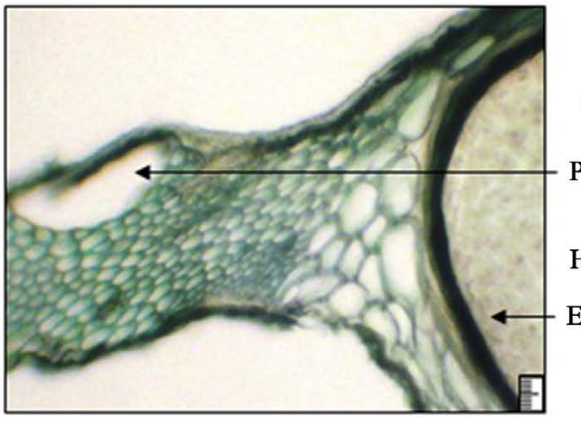

(e)

$100 \mu \mathrm{m}$

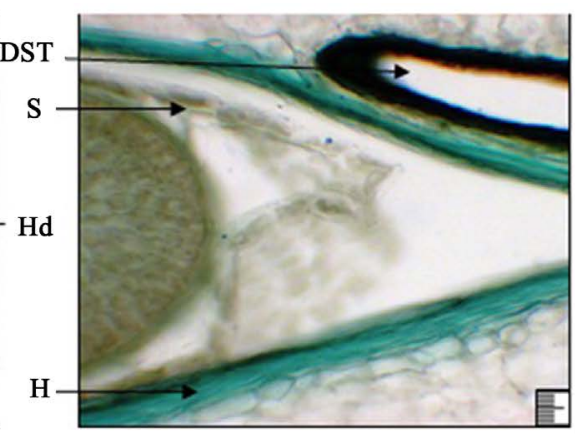

(b)

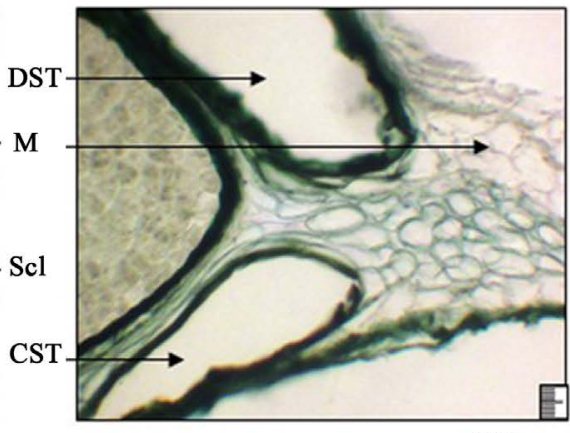

(d)

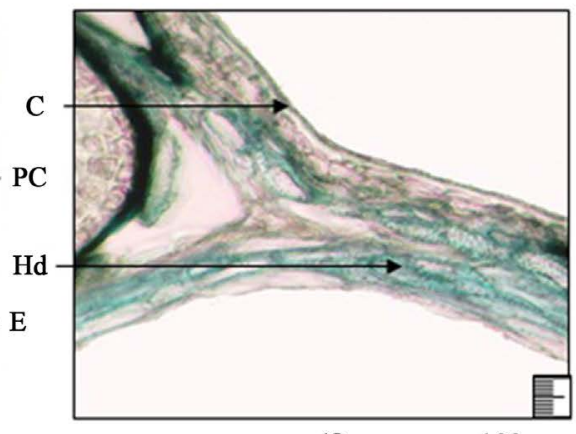

(f)

$100 \mu \mathrm{m}$

Figure 4. Cross section mericarp marginal parts of species Ferula: (a) F. foetida; (b) F. varia; (c) F. kyzylkumica; (d) F. dshizakensis; (e) F. helenae; (f) F. angreni. Symbols: C-Cuticle, CST-Commissural Secretory Tubules, DST—Dorsal Secretory Tubules, E-Endosperm, H-Hypoendocarp, Hd-Hydrocyte Sells, M-Mesocarp, PC-Pneumatic Cavities, S-Spermoderm, Scl—Sclerenchyma. Drawing scale: (a)-(f) $-100 \mu \mathrm{m}$.

longer in F. dshizakensis. Epithelial cells dorsal, commissural and dorsal rib tubules longer, higher and wider it $F$. dshizakensis. The edge rib tubules higher and wider in $F$. angreni and $F$. kyzylkumica. A number of epithelial cells of dorsal, commissural and rib tubules greater in $F$. dshizakensis. Epithelial cells in the tubules intensely colored in $F$. varia. Fruit of $F$. dshizakensis are mall, but in proportion to the size of its mass is greater than that associated with major secretory tubules containing a large amount of resin. In fruits of petrophytes $-F$. helenae, F. dshizakensis, F. angreni in the marginal edge has pneumatic cavities.

$F$. dshizakensis and F. helenae previously considered as one species (http://www.theplantlist.org). The structure of the fetus showed their difference. 
Mericarp in F. helenae is oval in F. dshizakensis is obovated. Boundary edges $F$. helenae are short wing-shaped, in $F$. dshizakensis wide wing-shaped. In the apical part of $F$. dshizakensis there is a group of sclereids, in $F$. helenae they are absent. Boundary secretory tubules are absent in $F$. helenae. Commissural tubules in F. helenae (3 - 5), in F. dshizakensis (8 - 10). Weight of 1000 pcs. fruits of $F$. helenae-21.61 g, F. dshizakensis-38.95 g. Fruit of F. helenae sticky and has a specific smell (ventral fins between tubules filled with secret or resins).

\section{Conclusions}

It has been revealed that a various localizations of secretory structures in the pericarp of the fruit of Ferula species: secretory tubules of $F$. foetida pericarp are obliterated, which is associated with monocarp. In the pericarp of $F$. varia fruit, there are two types of secretory structures: dorsal and commissural. In the pericarp of F. kyzylkumica, F. helenae, F. dshizakensis and F. angreni fruit, there are three types: dorsal, commissural and costal. Taxonomic and ecological differentiation of species of the genus Ferula is reflected in a significant variety of secretory system. These signs of the fruit can be used for identification of plant material. Obliteration or less developed secretory tubule in the fruit of monocarp correlates with abundant accumulation of tar in the roots. In the polycarpic fruit, developed secretory tubules are correlated with a smaller size of the root, and hence a tar content. The structure of the fruit together with the structure of the leaf confirms the independence of $F$. helenae and $F$. dshizakensis species [8].

In Xeronarthex section species ( $F$. kyzylkumica, F. helenae, F. dshizakensis, F. angreni) most wide lumen dorsal tubules, secretory structure is more complex and advanced, which is associated with greater drought resistance of species. Their fruits are formed in the xerothermic period (June) and secretory structure of fruit in mind the presence of essential oils performs protecting function against ultraviolet radiation and increases drought tolerance. More complex secretion system is also an indicator of a higher evolutionary level of a taxon.

\section{References}

[1] Denisova, G.A. (1989) Terpenoid Containing Plant Structures. Nauka, Leningrad, 140.

[2] Pimenov, M.G. and Ostroumova, T.A. (2012) Umbrella (Umbelliferae) Russia. Association of Scientific Publications, Moscow, 477.

[3] Safina, L.K. (2012) Ferula Central Asia and Kazakhstan (Karpoanatomical Review). LEM, Almaty, 244.

[4] Korovin, E.P. (1947) An Illustrated Monograph of the Genus Ferula (Tourn.) L. Tashkent, 91.

[5] Pimenov, M.G. and Klyuykov, E.V. (2002) Umbrella (Umbelliferae) Kyrgyzstan. Association of Scientific Publications, Moscow, 288.

[6] Barykina, R.P. and Chubatova N.V. (2005) Large Workshop in Botany. Ecological Anatomy of Flowering Plants. Association of Scientific Publications, Moscow, 77.

[7] Zaitsev, G.N. (1991) Mathematics in Experimental Botany. Nauka, Moscow, 296.

[8] Sharipova, V.K. (2016) Adaptive Signs of Leaf Mining Species Ferula (Apiaceae Lindl.). Gulistan, 62-64. 
Submit or recommend next manuscript to SCIRP and we will provide best service for you:

Accepting pre-submission inquiries through Email, Facebook, LinkedIn, Twitter, etc. A wide selection of journals (inclusive of 9 subjects, more than 200 journals)

Providing 24-hour high-quality service

User-friendly online submission system

Fair and swift peer-review system

Efficient typesetting and proofreading procedure

Display of the result of downloads and visits, as well as the number of cited articles Maximum dissemination of your research work

Submit your manuscript at: http://papersubmission.scirp.org/

Or contact ajps@scirp.org 